BENM 2021

International Scientific and Practical Conference "Biotechnology, Ecology, Nature Management"

\title{
DETERMINATION OF THE MAXIMUM TEMPERATURE OF THE CONTENT OF CYPRINUS CARPIO
}

\author{
Yu. A. Kuchikhin (a)*, A. S. Shavrin (b), A. A. Zyulkin (c), T. P. Khairullina (d) \\ *Corresponding author
}

(a) K.G. Razumovsky Moscow State University of Technologies and Management (the First Cossack University), 73, Zemlyanoy Val str., Moscow, Russia, kuchikhin@gmail.com

(b) K.G. Razumovsky Moscow State University of Technologies and Management (the First Cossack University) 73, Zemlyanoy Val str., Moscow, Russia

(c) K.G. Razumovsky Moscow State University of Technologies and Management (the First Cossack University) 73, Zemlyanoy Val str., Moscow, Russia

(d) K.G. Razumovsky Moscow State University of Technologies and Management (the First Cossack University) 73, Zemlyanoy Val str., Moscow, Russia

\begin{abstract}
In commercial aquaculture, one of the most important indicators is the temperature in which the fish are kept. To create conditions, as close to ideal as possible, it is necessary to know various hydrochemical parameters, one of the most important is the water temperature. In various fish feeding discounts, the daily ration comes primarily from the water temperature, as well as the age of the fish. Sources for carp provide temperatures ranging from 18 to $25^{\circ} \mathrm{C}$, and it is noted that these temperatures are most suitable for commercial fish farming. However, the works do not give the maximum limiting temperature of the content. This article presents a study on the maximum temperature of the content of Cyprinus carpio in the conditions of closed water supply installations according to the parameters of feed consumption. As a result of the work, the maximum temperature of koi carp keeping was determined. It is also possible that breeding carp at high temperatures will significantly increase fish productivity, while not significantly increasing the dose of feeding
\end{abstract}

2672-8575 (c) 2022 Published by European Publisher.

Keywords: Aquariums, Cyprinus carpio, food consumption, RAS, water temperature 


\section{Introduction}

Aquaculture is one of the most actively developing sectors of agriculture (United Nations Food and Agriculture Organization [FAO], 2018). Now, fish farming is ubiquitous not only in cage-type farms located in coastal areas and inland water bodies, but also based on recirculating water supply units (RAS) (Folke \& Kautsky, 1992). Growing fish under RAS conditions allows achieving: increasing the volume of fish products received round-the-clock control over the objects of cultivation, as well as reducing the cost of production (Pauly et al., 2014).

Enterprises specializing in the cultivation of freshwater culture objects in RAS are widespread in the territory of the Russian Federation. In particular, a large number of farms are located in the Belgorod region and in general in the south of Russia (Bychkova et al., 2020).

To achieve the maximum economic effect in each region, feed is used that is made from the most accessible and cheapest components, while maintaining the qualitative and quantitative composition, suitable for mass fish rearing (Ghaly et al., 2005). The key disadvantage of such feeds is the imbalance of trace element and vitamin composition. The deficiency of macro- and microelements in the diet of fish can affect not only the growth rate, but also, therefore, the time of obtaining marketable products and the quality of fish meat (Hussain et al., 2014).

In commercial aquaculture, fish temperature is one of the most important indicators (Crivelli, 1981). To create conditions, as close to ideal as possible, it is necessary to know various hydrochemical parameters, one of the most important is the water temperature (Mustafa et al., 2012). In various fish feeding discounts, the daily ration comes primarily from the water temperature, as well as the age of the fish.

\section{Problem Statement}

In various fish feeding discounts, the daily ration comes primarily from the water temperature, as well as the age of the fish. Sources for carp provide temperatures ranging from 18 to $25^{\circ} \mathrm{C}$ and note that these temperatures are most suitable for commercial fish farming (Goolish \& Adelman, 1984). However, the works do not give the maximum limiting temperature of the content, for fish of different species, including carp.

\section{Purpose of the Study}

In such conditions, studies of the permissible temperatures of the content of freshwater aquaculture objects are relevant. This article presents a study on the maximum temperature of the content of Cyprinus carpio in the conditions of closed water supply installations in terms of feed consumption parameters.

\section{Research Methods}

For the experiment, a model setup was created, the habitat conditions in which are simulated by conditions corresponding to installations in industrial aquaculture. For this, five aquariums with a volume of 50 liters were taken. The water in the aquariums corresponded to the needs of the fish and was kept for 
24 hours. Each aquarium has been fitted with Barbus Heater 200w heaters, designed for aquariums up to 100 liters in volume and capable of maintaining temperatures between $20^{\circ} \mathrm{C}$ and $36^{\circ} \mathrm{C}$. The temperature of the sensors was adjusted to $23^{\circ} \mathrm{C}$. An internal circulation pump was also installed with the function of supplying oxygen, with a capacity of up to $2001 / \mathrm{h}$. The lighting throughout the experiment was natural, without the use of lamps.

The fish were transferred to prepared aquariums, 5 individuals in each.

Each fish was individually weighed on a DL-120 wp electronic scale to determine the total weight and average of one fish in all aquariums. The average fish weight is shown in table 1.

Table 1. Average weight in each group

\begin{tabular}{ccccc}
\hline Group 1 & Group 2 & Group 3 & Group 4 & Group 5 \\
\hline $10,237 \pm 2,15$ & $10,0506 \pm 2,075$ & $10,6272 \pm 2,542$ & $10,1352 \pm 2,356$ & $10,2670 \pm 2,196$ \\
\hline
\end{tabular}

The fish were placed in a model setup at the primary keeping temperature $\left(19^{\circ} \mathrm{C}\right)$, and within 24 hours, the temperature was increased to the values required for the experiment. Temperature values in each experimental group are: 1 group $-20+-1^{\circ} \mathrm{C}$; Group $2-24+-1{ }^{\circ} \mathrm{C}$; Group $3-28+-1{ }^{\circ} \mathrm{C}$; Group $4-33+-1^{\circ} \mathrm{C}$; Group $5-36+-1^{\circ} \mathrm{C}$.

Determination of the maximum temperature was determined by the maximum one-time food intake in the study group. Alltech Coppens Pre Grower-18 food was used for the experiment, with a granule size of $2 \mathrm{~mm}$. The granule size is commensurate with the age characteristics of the fish. The nutritional value of the feed and its composition are presented in table 2.

Table 2. Nutritional value of the feed

\begin{tabular}{crrrrrr}
\hline Protein & \multicolumn{1}{c}{ Fats } & Phosphorus & \multicolumn{1}{c}{ Fiber } & \multicolumn{1}{c}{ Ash } & \multicolumn{1}{c}{ Calcium } & Sodium \\
\hline $45 \%$ & $18 \%$ & $1,39 \%$ & $1,7 \%$ & $8,5 \%$ & $1,7 \%$ & $0,4 \%$ \\
\hline
\end{tabular}

The amount of feed was determined by the calculation-experimental method and was determined from the volumes that the fish would not be able to consume. It was decided to feed the fish $6 \%$ of their maximum weight. The food was weighed on an And GR-200 scale separately for each aquarium and placed in glass tubes.

In 1.5 hours, the food is completely consumed, but the food does not have time to be utilized from the gastrointestinal tract. After a specified time had elapsed, the digestive tract was removed from the fish and its contents were weighed. The contents are transferred to Petri dishes, weighed on the DL-12wp scale and the ratio of feed introduced into the aquarium and consumed is compared. The food that is pulled out of the digestive tract contains moisture. To determine the content of dry food in the suspended contents, two samples were taken from each aquarium. The samples were transferred to a glass bowl and placed in a temperature cabinet for 10 minutes at a temperature of 110 degrees. We took it out after drying and weighed it. After recalculation in accordance with the removed moisture, the weight of the feed was $50 \%+-5 \%$ of the wet content.

The results obtained for the consumed feed in each group are presented in table 3 . 
Table 3. Feed intake data

\begin{tabular}{ccccc}
\hline Group number & Temperature, $^{\circ} \mathbf{C}$ & Weight g & Feed weight g & $\begin{array}{c}\text { Feed weight } \\
\text { consumed g }\end{array}$ \\
\hline 1 & 20 & 11,12 & 3,6 & 1,308 \\
2 & 24 & 11,23 & 3,24 & 1,856 \\
3 & 28 & 10,92 & 3,18 & 1,526 \\
4 & 33 & 11,14 & 3,36 & 2,604 \\
5 & 36 & 10,98 & 3,3 & 0,487 \\
\hline
\end{tabular}

Standard deviations for fish weight and trumpet weight are shown in Figure 1.
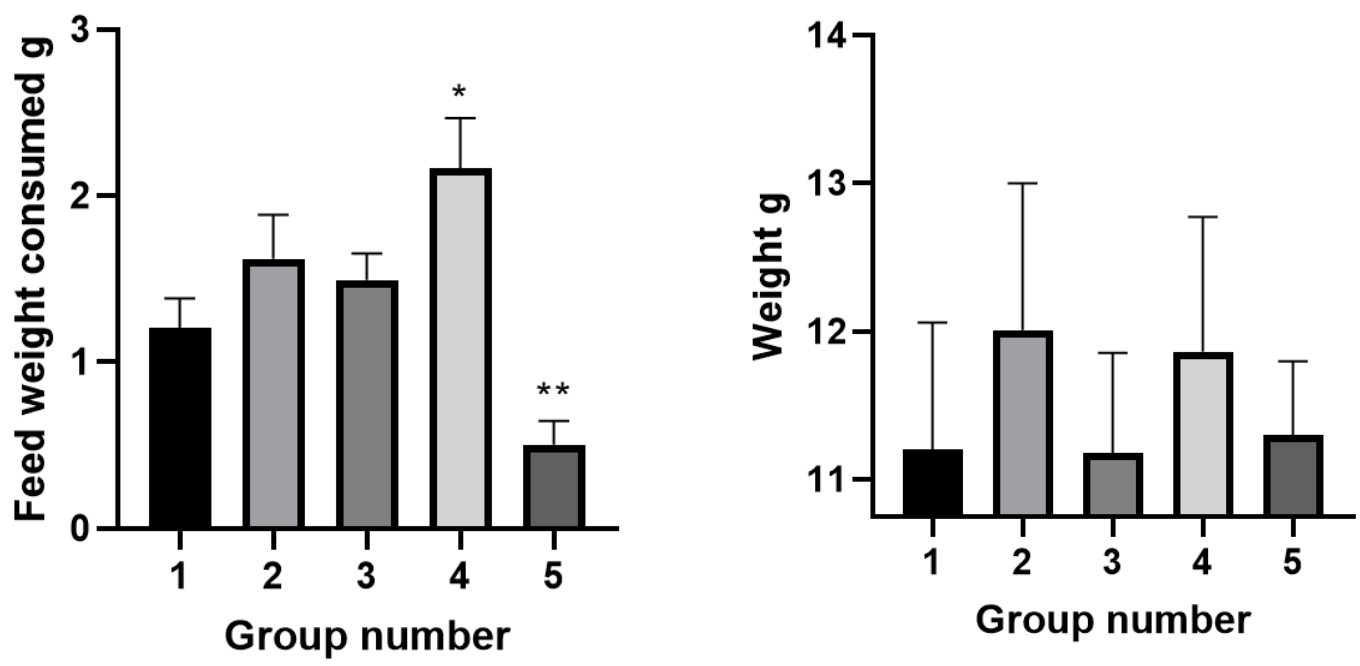

Figure 1. Difference for feed consumed by groups with standard deviation. Comparison was made using non-paired Student's t-test $(\mathrm{P}<0.05)$

\section{Findings}

When determining the results of the effect of temperature on feed consumption, the maximum amount of feed consumed for a certain period was calculated. The amount of food in each study group is presented in table 4 .

Table 4. Feed weight for each group

\begin{tabular}{cccccc}
\hline Group number & $\mathbf{1}$ & $\mathbf{2}$ & $\mathbf{3}$ & $\mathbf{4}$ & $\mathbf{5}$ \\
\hline Feed weight g & 3,624 & $3,245 \Gamma$ & $3,186 \Gamma$ & $3,366 \Gamma$ & $3,315 \Gamma$ \\
\hline
\end{tabular}

As can be seen from Table 4 of standard deviations in the case of control groups 1, 2 and 3 with a temperature regime of 20,24 and $28^{\circ} \mathrm{C}$, respectively, the amount of food consumed did not differ significantly, so there is no significant difference between the content of this species within these temperatures. 
The best indicator of food consumption was observed in-group No. 4, and amounted to $77.36 \%$ of the applied food, which is the best indicator among all control groups, and is $4.65 \%$ of the total weight of fish in this group.

The total amount of dry food consumed for each aquarium is shown in Table 5.

Table 5. Consumed dry food

\begin{tabular}{cccccc}
\hline Group number & Group 1 & Group 2 & Group 3 & Group 4 & Group 5 \\
\hline Dry weight g & 1,308 & 2,133 & 1,526 & 2,604 & 0,487 \\
\hline
\end{tabular}

In-group No. 5, the behavior of the fish was inhibited, and an extremely weak reaction to food, inactive consumption was observed. With a further increase in temperature, the fish completely stopped responding to food, stopped moving, and did not react to external stimuli. As a result of the work, the maximum temperature of koi carp keeping was determined.

Thus, the utility data obtained in this work confirm the assumptions that Cyprinus carpio can be solicited under conditions of elevated temperatures (Ang et al., 2021; Rijkers et al., 1980). It is also possible that breeding carp at high temperatures will significantly increase fish productivity, while not significantly increasing the dose of feeding.

\section{Conclusion}

1. According to the data obtained in the first three groups, consumption did not differ significantly, which cannot be considered a significant difference. In this case, it was found that fish kept at temperatures between 20 and $28^{\circ} \mathrm{C}$ have the same daily diet.

2. The study determined the maximum acceptable temperature for keeping this species at around $33^{\circ} \mathrm{C}$. At this temperature, the behavior of the fish is quite active and there is a maximum feed intake.

3. The purpose of the work was to determine the maximum temperature of the koi carp content in the conditions of closed water supply installations, which was achieved. While maintaining such temperature regimes, industrial production of this type can be accelerated, while the costs of temperature installations and their maintenance increase. It is advisable to maintain this temperature when breeding the high-value subspecies Cyprinus carpio.

\section{References}

Ang, J., Pierezan, F., Kim, S., Heckman, T. I., Sebastiao, F. A., Yazdi, Z., Abdelrazek, S. M. R., \& Soto, E. (2021). Use of topical treatments and effects of water temperature on wound healing in common carp (Cyprinus carpio). Journal of Zoo and Wildlife Medicine, 52(1), 103-116. https://doi.org/10.1638/2020-0072

Bychkova, L. I., Nikiforov-Nikishin, D. L., Ponomarev, A. K., \& Bugaev, O. G. (2020). Evaluating the UV radiation effectiveness in industrial aquaculture IOP Conference Series: Earth and Environmental Science. IOP Publishing, 548(4), 042046. https://doi.org/10.1088/1755$1315 / 548 / 4 / 042046$

Crivelli, A. J. (1981). The biology of the common carp, Cyprinus carpio L. in the Camargue, southern France. Journal of fish Biology, 18(3), 271-290. https://doi.org/10.1111/j.10958649.1981.tb03769.x 
United Nations Food and Agriculture Organization [FAO]. (2018). The State of World Fisheries and Aquaculture 2018: Meeting the sustainable development goals. FAO.

Folke, C., \& Kautsky, N. (1992). Aquaculture with its environment: prospects for sustainability. Ocean \& coastal management, 17(1), 5-24. https://doi.org/10.1016/0964-5691(92)90059-T

Ghaly, A. E., Kamal, M., \& Mahmoud, N. S. (2005). Phytoremediation of aquaculture wastewater for water recycling and production of fish feed. Environment international, 31(1), 1-13. https://doi.org/10.1016/j.envint.2004.05.011

Goolish, E. M., \& Adelman, I. R. (1984). Effects of ration size and temperature on the growth of juvenile common carp (Cyprinus carpio L.). Aquaculture, 36(1-2), 27-35. https://doi.org/10.1016/00448486(84)90051-6

Hussain, T., Verma, A. K., Tiwari, V. K., Prakash, C., Rathore, G., Shete, A. P., \& Nuwansi, K. K. T. (2014). Optimizing koi carp, Cyprinus carpio var. koi (Linnaeus, 1758), stocking density and nutrient recycling with spinach in an aquaponic system. Journal of the World Aquaculture Society, 45(6), 652-661. https://doi.org/10.1111/jwas. 12159

Mustafa, S. A., Davies, S. J., \& Jha, A. N. (2012). Determination of hypoxia and dietary copper mediated sub-lethal toxicity in carp, Cyprinus carpio, at different levels of biological organisation. Chemosphere, 87(4), 413-422. https://doi.org/10.1016/j.chemosphere.2011.12.037

Pauly, D., Belhabib, D., Blomeyer, R., Cheung, W. W. W. L., Cisneros-Montemayor, A. M., Copeland, D., Harper, S., Lam, V. W. Y., Mai, Y., Le Manach, F., Österblom, H., Mok, K. M., van der Meer, L., Sanz, A., Shon, S., Sumaila, U. R., Swartz, W., Watson, R., Zhai, Y., \& Zeller, D. (2014). China's distant-water fisheries in the 21st century. Fish Fish, 15(3), 474-488. https://doi.org/10.1111/faf.12032

Rijkers, G. T., Frederix-Wolters, E. M., \& Van Muiswinkel, W. B. (1980). The immune system of cyprinid fish. Kinetics and temperature dependence of antibody-producing cells in carp (Cyprinus carpio). Immunology, 41(1), 91. 